\title{
Braking System of Go-Kart
}

\author{
Masood M ${ }^{1}$, Appam Nihar ${ }^{2}$, Syed Najam $\mathrm{Ali}^{3}$, Mohd Sayeed ${ }^{4}$ \\ Professor and Director R\&D, Mechanical Department, Lords Institute of Engg \& Tech, Hyderabad, India ${ }^{1}$ \\ Assistant Professor, Mechanical Department, Lords Institute of Engg \& Tech, Hyderabad, India ${ }^{2}$ \\ Student, Mechanical Department, Lords Institute of Engg \& Tech, Hyderabad, India ${ }^{3,4}$
}

\begin{abstract}
This report documents the process and methodology to produce a low cost go-kart which is comfortable, vulnerable, durable and complete in all aspects by modeling it with CAD software The feasibility of the go-kart design was examined through FMEA, Cost report. The team focuses on a technically sound vehicle which is backed by a profound design and good manufacturing practices. The report explains approach, reasons, selecting criteria and expected working of the vehicle parameters. The procedural way of explanation is used for different parts of the vehicle, which starts from approach with the help of known facts, then the design and calculation procedure has been explained. The best way known had been use to go on to the final result of all parameters.
\end{abstract}

Keywords: Braking System, Go-Kart, FMEA, Cost report, CAD software.

\section{DESIGN METHODOLOGY}

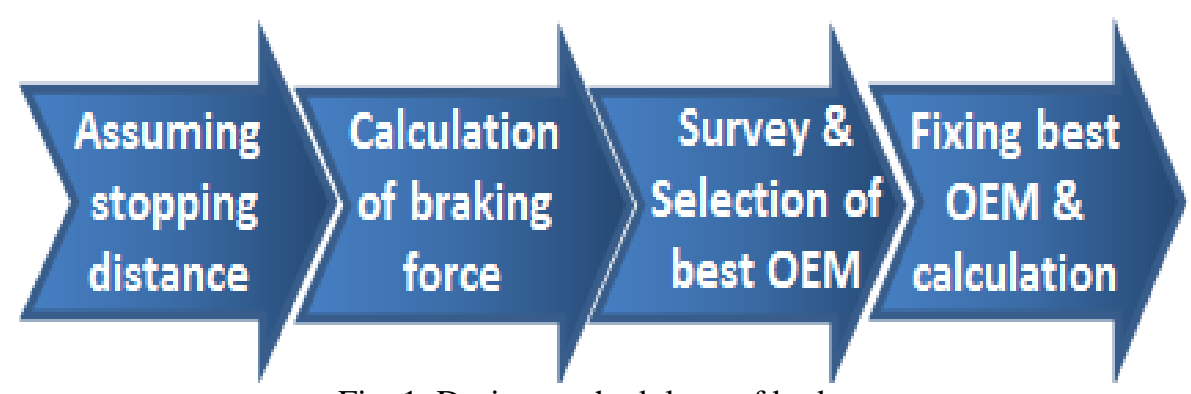

Fig. 1. Design methodology of brakes

\section{INTRODUCTION}

A brake is a device by means of which artificial frictional resistance is applied to a moving machine member, in order to retard or stop the motion of machine.

Brakes are generally applied to rotating axles or wheels but may also take other forms such as surface of a moving fluid (flaps developed into water or air).Some vehicles used combination of braking mechanism, such as drag racing car's with both wheel brakes and a parachute, or airplanes with both wheel brakes and drag flaps rise into the air during landing. Most brakes commonly use friction between two surfaces press together to convert the kinetic energy of the moving object into heat, through other methods of energy conversion may be employed.

\section{BRAKING SYSTEM}

A. Goals

- To design a braking system that is simple and ensures safety of the driver.

- To design a braking system which takes least time to bring the vehicle to stop

B. Selection of brakes

We are using disc brake for rear wheel considering the respective advantages, availability, and their limitations. The following reasons support the selection of disc brakes for the front and rear wheels.

- Disk brake contributes for reduction in overall weight of the vehicle.

- More braking torque needs to be generated by the Rear brake even after weight transfer, because the single brake has to manage the braking torque requirement of the entire rear driveshaft

1) Brake Caliper: For achieving a better braking efficiency and to improve the vehicle braking effect we have opted to use double piston single calipers for all rear wheels 


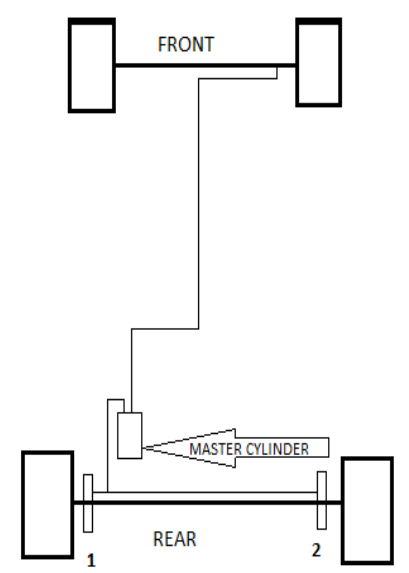

Fig. 2.Layout of braking circuit

\section{CALCULATIONS}

A. Required Calculations

Where

Height of centre of gravity $=1.01746 \mathrm{~m}$

$\mathrm{h}=0.08824 \mathrm{~m}$

Let us assume the static weight distribution ratio be 40:60

Stopping distance $=2 \mathrm{~m}$

1) Gross weigh $\mathrm{t}=\mathrm{g} *$ weight of vehicle

$$
\begin{aligned}
& =9.81 * 140 \\
& =1373.4
\end{aligned}
$$

2) Brake line pressure $(P)$

$$
\begin{aligned}
& =\text { force on brakes / area of master cylinder } \\
& =4 * 350 / 0.785 *(0.01)^{2} \\
& =17.83 \mathrm{MPa}
\end{aligned}
$$

3) Clamping force

$$
\begin{aligned}
& =\text { Brake line pressure } * \text { area of caliper piston } * 2 \\
& =17.8343 * 0.785 *\left(25.4 * 10^{-3}\right)^{2} * 2 \\
& =18064.6825 \mathrm{Nm}
\end{aligned}
$$

4) Rotating force

$=\mathrm{CF} *$ no of caliper piston $*$ coefficient of friction

$=18064.6825 * 2 * 0.8$

$=10838.6825 \mathrm{~N}$

5) Static weight on front axle

$$
\begin{aligned}
& =(0.4 \text { xvehicle weight }) \\
& =(0.4 \times 1372.94) \\
& =549.17 \mathrm{~N}
\end{aligned}
$$

6) Static weight on rear axle

$$
\begin{aligned}
& =(0.6 \mathrm{x} \text { vehicle weight }) \\
& =(0.6 \mathrm{x} 1372.94) \\
& =823.76 \mathrm{~N}
\end{aligned}
$$

Let us take stopping distance as $2 \mathrm{~m}$.

From Newton's laws of motion

$$
v^{2}-u^{2}=2 a s
$$

Where

$\mathrm{V}$ is velocity after braking $=0 \mathrm{~m} / \mathrm{s}^{2}$

$\mathrm{u}$ is velocity before braking $=32.77 \mathrm{~m} / \mathrm{s}^{2}$

(i.e., the maximum velocity of the vehicle)

7) Dynamic weight transfer

$$
\begin{aligned}
& =(\mathrm{h} \times \text { wt } \mathrm{x} \text { deceleration } / \mathrm{h} \text { c.o.g } \times 9.81) \\
& =(0.08824 \times 1372.94 * 73.15 / 1.01 * 9.81) \\
& =903 \mathrm{~N}
\end{aligned}
$$


8) Dynamic weight on front axle:

$$
\begin{aligned}
& =(\text { static front weight }+ \text { dynamic weight transfer }) \\
& =549+903 \\
& =1452 \mathrm{~N}
\end{aligned}
$$

9) Dynamic weight on one front wheel:

$$
\begin{aligned}
& =(\text { Dynamic weight on front axle } / 2) \\
& =1452 / 2 \\
& =726 \mathrm{~N}
\end{aligned}
$$

10) Dynamic weight on rear axle

$=$ static rear weight + dynamic weight transfer

$=(823.76+903)$

$=1726.76 \mathrm{~N}$

11) Frictional force at each front wheel

$=(0.4 \mathrm{xDynamic}$ weight on one front wheel $)$

$=0.4 \times 726$

$=290.4 \mathrm{~N}$

12) Frictional force at each rear wheel

$=(0.6 x$ Dynamic weight on rear axle

$=0.6 \times 1726.76$

$=1036.05 \mathrm{~N}$

TABLE I CALCULATED VALUES RESULT

\begin{tabular}{|c|c|}
\hline Parameter & Value \\
\hline Pedal effort & $178 \mathrm{~N}$ \\
\hline Adhesion factor of road & 0.4 \\
\hline Coefficient of friction between brake pads and rotor & 0.4 \\
\hline Stopping distance & $2 \mathrm{~m}$ \\
\hline Stopping time & $0.1893 \mathrm{sec}$ \\
\hline
\end{tabular}

B. Obtained Calculations

The calculations are same for both front and rear wheel brakes, up to the brake line after master cylinder.

Estimated speed of the vehicle $=118 \mathrm{Kmph}$

Estimated pedal effort of the driver $=178 \mathrm{~N}$

Mechanical advantage or pedal ratio $=4: 1$

Force acting on master cylinder

$$
\begin{aligned}
& =(\text { Estimated pedal effort of the driverx } 4) \\
& =178 \times 4 \\
& =712 \mathrm{~N}
\end{aligned}
$$

Diameter of master cylinder $=0.75 "=19.05 \mathrm{~mm}$

Area of master cylinder $=285 \mathrm{~mm}^{2}$

Pressure acting on master cylinder $=$ (force $\mathrm{x}$ area $)$

$$
\begin{aligned}
& =712 \times 285 \\
& =202920 \mathrm{~N} / \mathrm{mm}^{2}
\end{aligned}
$$

For Rear wheel (Disc Brake)

Area of piston in the calipers $=3086 \mathrm{~mm}^{2}$

Pressure acting in the master cylinder $=$ Pressure in the calipers.

Force acting on calipers $=$ Pressure $\mathrm{x}$ area

$$
\begin{aligned}
& =202920 \times 3086 \\
& =626.211 \mathrm{~N} / \mathrm{m}^{\wedge} 2
\end{aligned}
$$

Coefficient of friction between pad and rotor $=0.4$

Friction force between disc and pad

$$
\begin{aligned}
& =\text { clamping force } \mathrm{x} \text { coefficient of friction } \\
& =1594.2550 .4 \\
& =637.702 \mathrm{~N}
\end{aligned}
$$


Effective radius of rear disc $=114.3 \mathrm{~mm}$

Torque developed $=11.4 \mathrm{~N}-\mathrm{m}$

Effective rolling radius of rear wheel $=304.8 \mathrm{~mm}$

Braking force acting on single rear tire

$$
=(\text { Torque } / \text { tire radius })=6206.83
$$

Deceleration $=\mathrm{Bf} / \mathrm{m}=44.33 \mathrm{~m} / \mathrm{s}$

\section{TABLE II OBTAINED VALUES RESULT}

\begin{tabular}{|c|c|}
\hline Parameter & Value \\
\hline Braking torque & $1083.868 \mathrm{~N}$ \\
\hline Braking force at rear & $6206.83 \mathrm{~N}$ \\
\hline
\end{tabular}

The master cylinder piston diameter that was calculated is the maximum possible diameter that can be used for safe braking. The team decided to use a master cylinder with $10 \mathrm{~mm}$ piston diameter as it can provide better braking force and is also commonly found on bikes.

\section{CONCLUSION}

We calculated all the design parameters and analysed the brake layout, brake disc, etc. Thus after all the test and calculation we have concluded that our design is safe for fabrication.

\section{ACKNOWLEDGMENTS}

The team expresses its sincere gratitude to Dr. Masood M Professor and Director (R\&D),(Mechanical) for their continuous support and encouragement. We are also thankful to our faculty advisor Mr. Appam Nihar for the valuable advice and supervision.

\section{REFERENCES}

Racing and Sports Kart Chassis Design by Michael Costin and David Phipps

Mechanics of Materials by Beer and Johnston

www.kartpedia.com

Wikipedia

5. Anjul Chauhan Lalit Naagar Sparsh chawla Design and Analysis of a Go-Kart, International Journal of Aerospace and Mechanical Engineering volume 3 - no.5, September 2016

6. Automobile Engineering by R.K Rajput

7. Theory of Machines, by R.S Khurmi, JK Gupta

8. Machine Design by R.S Khurmi, JK Gupta 